GESTURES OF CONCERN 
A Cultural Politics Book

Edited by John Armitage, Ryan Bishop, and Douglas Kellner 


\section{GESTURES OF}

\section{CONCERN}

Chris Ingraham

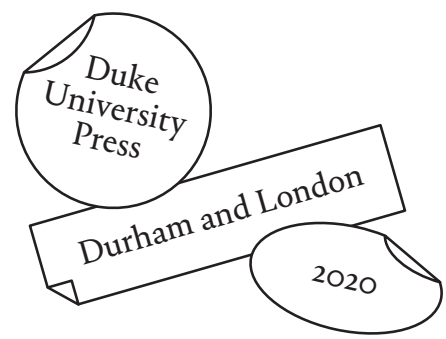


(C) 2020 Duke University Press

All rights reserved

Printed in the United States of America on acid-free paper $\infty$ Designed by Drew Sisk

Typeset in Portrait Text and Univers by Westchester

Publishing Services

Library of Congress Cataloging-in-Publication Data

Names: Ingraham, Christopher, [date] author.

Title: Gestures of concern / Chris Ingraham.

Description: Durham : Duke University Press, 2020. | "A cultural politics book." | Includes bibliographical references and index. Identifiers: LCCN 2019051656 (print) | LCCN 20I9051657 (ebook) ISBN 978I478008583 (hardcover) ISBN 978I4780095II (paperback) ISBN 978I4780I2I77 (ebook)

Subjects: LCSH: Politics and culture. | Social change-Citizen participation. | Political participation-Social aspects. |

Communication and culture.

Classification: LCC JA75.7 .I54 2020 (print) | LCC JA75.7 (ebook) | DDC 306.2-dc23

LC record available at https://lccn.loc.gov/2019051656

LC ebook record available at https://lccn.loc.gov/2019051657

Cover art: Adam Milner, Petals (in der Ferne locker, zu Hause unter Druck... FOCUS 42/20I5, page 6), 2017, interior latex paint on magazine page. Courtesy of the artist. 
THE AFFECT OF ABSTRACT EXCHANGE, THE FEELING THAT EVERYTHING IS FUNGIBLE - WHAT IS ITS SONG?

-Ben Lerner, The Hatred of Poetry 
This page intentionally left blank 